\title{
BASIC REACTIONS OF OSTEOBLASTS ON STRUCTURED MATERIAL SURFACES
}

\author{
U. Meyer $^{1 *}$, A. Büchter ${ }^{1}$, H.P. Wiesmann ${ }^{1}$, U. Joos ${ }^{1}$ and D.B. Jones ${ }^{2}$, \\ ${ }^{1}$ Department of Cranio-Maxillofacial Surgery, University of Münster, Germany \\ - Biomineralisation research unit - \\ ${ }^{2}$ Institute for Experimental Orthopaedics and Biomechanics, University of Marburg, Germany
}

\begin{abstract}
In order to assess how bone substitute materials determine bone formation in vivo it is useful to understand the mechanisms of the material surface/tissue interaction on a cellular level. Artificial materials are used in two applications, as biomaterials alone or as a scaffold for osteoblasts in a tissue engineering approach. Recently, many efforts have been undertaken to improve bone regeneration by the use of structured material surfaces. In vitro studies of bone cell responses to artificial materials are the basic tool to determine these interactions. Surface properties of materials surfaces as well as biophysical constraints at the biomaterial surface are of major importance since these features will direct the cell responses. Studies on osteoblastlike cell reactivity towards materials will have to focus on the different steps of protein and cell reactions towards defined surface properties. The introduction of new techniques allows nowadays the fabrication of materials with ordered surface structures. This paper gives a review of present knowledge on the various stages of osteoblast reactions on material surfaces, focused on basic cell events under in vitro conditions. Special emphasis is given to cellular reactions towards ordered nano-sized topographies.
\end{abstract}

Key words: Biomaterials, tissue engineering, osteoblasts, cell culture

*Address for correspondence:

Ulrich Meyer, MD, DMD, $\mathrm{PhD}$

Department of Cranio-Maxillofacial Surgery

University of Münster

Waldeyerstr. 30

D-48149 Münster

Germany

Telephone Number: 492518347201

FAX Number: 492518347203

E-mail: ulrich.meyer@ukmuenster.de

\section{Introduction}

Recently, many efforts have been undertaken to improve bone regeneration by the use of acellular or cellular implant materials. The nature of the bone-implant interface in the clinical situation is determined by many factors resulting in different cellular responses to the implant system both in experimental and clinical situations (Oreffo and Triffitt, 1999). Because bone/biomaterial interactions take place at the material surface, osteoblasts covering the implant surface are the crucial cells determining the tissue response at the biomaterial surface. The process of cell interaction on materials is highly dynamic and depends on various parameters influencing the cell responses (Anselme 2000, Figure 1). It is a step by step process from the initial contact to a long term cell response. The whole interaction can be divided into different acellular and cellular events. Protein adsorption is believed to be the first event that takes place after contact of body fluids and is influenced by physico-chemical characteristics of the material. It is followed by the attachment phase which occurs rapidly (Boyan et al., 1996, Meyer et al., 1997) The adhesion phase occurs over longer periods and involves various biological molecules (extracellular matrix proteins, cell membrane proteins, and cytoskeleton proteins) which interact together to induce the subsequent cell response in terms of migration and differentiation. A bone-like mineral formation at the material surface should be the ultimate stage of a bonelike osteoblast reaction (Davies et al., 1990). The outcome of the long term osteoblast reaction is further influenced by the biophysical (mechanical and electrical) environment which will be present at the material/cell interface under functional conditions. In this respect, it is important to realise that the above mentioned features take place on all substitute systems independently of their composition.

This paper gives a review of present knowledge on the various stages of osteoblast reactions on material surfaces, focused on basic cell events on structured surfaces in vitro. Structured surface characteristics of materials with special respect to their physico-chemical influences towards osteoblasts will be emphasised. The aim of this review is to highlight useful information for the understanding of osteoblast/surface interactions in order to improve present and future biomaterials.

\section{Osteoblast Cell Lines}

In vitro models of bone-like cell behaviour have been widely used based on the success of osteoblast cell cultures (for review see Oreffo and Triffitt (1)). Different culture 


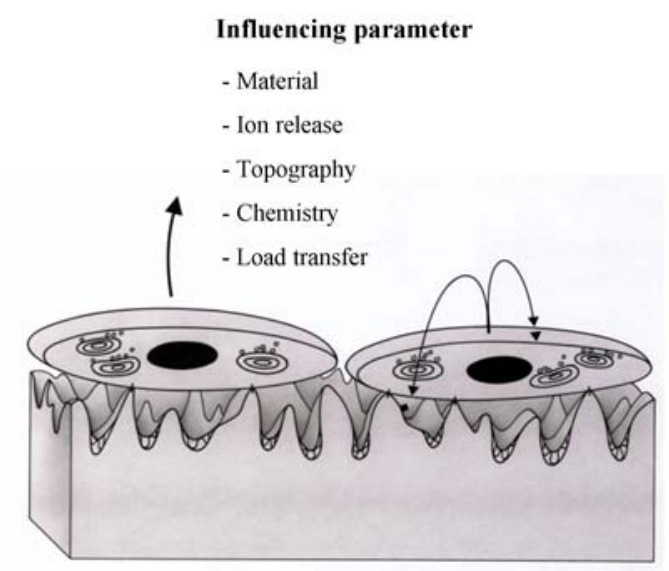

Figure 1: Influencing material surface parameter on osteoblast behaviour.

systems have been used: (1) osteosarcoma cell lines; (2) intentionally immortalised cell lines; (3) nontransformed clonal cell lines, (4) primary cultures (eg. bone marrow stromal cells, intramembranous bone or periostal derived cells) (Burger et al., 1995; Cooper et al., 1998; Davies et al., 1986; Jones et al., 1991; Macnair, 1997). Concerning the use of the various cell culture methods in testing of material surfaces it is important to recognise the characteristics of each cell system.

Osteosarcoma cell lines are known to display patterns of gene expression, modes of adhesion, or signal transduction pathways that are based on a particular stage of differentiation. Most cell lines do not demonstrate a complete pattern of in vitro differentiation. The development of established clonal osteoblast-like cells from rat osteosarcomas (MG-63, UMR and ROS series) provided cell lines that were homogeneous, phenotypically stable, easy to propagate and maintain in culture (Yamagushi et al., 1998). They expressed many of the properties of nontransformed osteoblasts. But, as with cancer cells, these cells are transformed and display an aberrant genotype, have an uncoupled adhesion/division relationship, demonstrate a substrate independent attachment and, exhibit phenotypic instability in long term culture. Therefore, these osteoblast-like cells do not reflect the normal phenotype of primary osteoblast-like cells. Therefore, a substrate dependent cell reaction is difficult to assess.

Other approaches have been done by using clonally derived immortalised or spontaneously immortalised cell lines (neonatal mouse MC3T3E1 and fetal rat RCJ cell lines; Elgendy et al., 1993; Grigordias et al., 1990). Although none of these lines behaves exactly alike and the results of experiments with them differ in detail (Aubin, 1998), they do have some common features (alkaline phosphatase activity, collagen type I production, bone-like nodule formation). Despite these common features cells can be in different stages of growth and development under cell culture conditions. They have therefore various phenotypic expressions, depending on the cell culture situation. Conditionally transformed immortalized human osteoblast cell lines were developed by various researchers aimed to investigate the behaviour of osteoblasts towards external stimuli. Xiaoxue and co-worker (2004) for example evaluated the generation of an immortilized human stromal cell line, which contains cells able to differentiate into the osteoblastic cell line. Concerning the use of immortalised cells in biomaterial testing it is important to recognise that all cell lines impose the disadvantage of having unique phenotypes, so that the morphological sensitivity towards a changing environment (material surface) is impaired.

Non-transformed and primary cultured osteoblasts display in this respect a well-defined inverse relationship of proliferation and differentiation (Owen et al., 1990). Measures of osteoblast-specific matrix protein expression define valuable reference points used in observation of regulated osteoblast physiology especially when a substratum dependent reaction is under investigation. They have the advantage of an environmental dependent cell behaviour. Oreffo and Triffitt (1999) demonstrated that primary cells are able to react sensitively to minor alterations of their surrounding, a key feature which is advantageous in surface testing. To evaluate osteoblast reactions on biomaterial surfaces the use of primary and non-transformed cells seems therefore to be advisable. Concerning the use of primary osteoblast-like cells in testing of artificial surface it is important to recognise that the reaction of cells towards the material is also dependent on the cellular maturation stage (Boyan et al., 1996). Additionally, it should be emphasised that the behaviour of osteoblasts on artificial surfaces is dependent on the experimental cell culture conditions (for review see Coehlo and Fernandes, 2000). There are a number of parameters that influence the expression of the osteoblastic phenotype in cell culture, most important the culture medium, culture time, number of passages and the presence of compounds. The presence of ascorbic acid, $\beta$-glycerophosphate and dexamethasone influence the in vitro behaviour of osteoblast-like cells. It is known that ß-glycerophosphate for example may allow (under some circumstances ectopic) mineral formation in osteoblast-like cell cultures. Dexamethasone is described as inducing cell differentiation and reducing cell proliferation, indicative for a reciprocal and functionally coupled relationship between proliferation and differentiation. Therefore, it is convenient to select suitable experimental conditions, but the culture conditions should be well defined in order to compare results from material testing by osteoblast-like cells in-vitro.

\section{Materials}

Application of biomaterials can be conceptualised as the use of materials to replace lost structures, augment existing structures or promote new tissue formation (Burg et al., 2000). Common degradable and non-degradable implant materials can be divided into synthetically produced metals and metal alloys, ceramics, polymers, and composites or modified natural materials (Meyer et al., 2004a). Whereas non-resorbable materials like steel or titanium alloys are 
commonly used for prosthetic devices, resorbable bone substitute materials are mainly investigated for their feasibility in bone replacement therapies. Various approaches used in the design of bone substitute materials have focused on the degradation and ultimate replacement of the material with new tissue. Whether or not a material is biodegradable, its surface properties will influence the initial cellular events at the cell-material interface. The difference in the two groups is the fact that the influence of the material surface towards osteoblasts is changing in degradable materials and therefore depends on the stage of degradation (Meyer et al., 2004b). While the inclusion of materials requirements is standard in the design process of implants or engineered bone substitutes, it is also critical to incorporate the cellular behaviour of osteoblasts towards the material surface in order to engineer a clinically relevant device. Four types of materials have been experimentally and/or clinically studied as bone substitute materials or scaffold materials for applications in tissue engineering: (A) various groups of synthetic organic materials including (I) biodegradable and bioresorbable polymers which have been used for clinically established products, such as polyglycolide, optically active and racemic polylactides, polydioxanone, and polycaprolactone; (II) polymers which are under current clinical investigation, such as polyorthoester, polyanhydrides, and polyhydro-xyalkanoate; and (III) entrepreneurial polymeric biomaterials, such as poly (lactic acid-co-lysine); (B) synthetic inorganic materials (e.g. hydroxyapatite, calcium/phosphate composites, glass ceramics); (C) organic materials of natural origin (e.g. collagen, fibrin, hyaluronic acid); and (D) inorganic material of natural origin (e.g. coralline hydroxyapatite). Several investigations have been published on the general properties and design features of these biodegradable and bioresorbable polymers and scaffolds (for review see Hutmacher, 2000). It is important to consider, that independent from the underlying material itself surface characteristics can differ. All biomaterials possess a complex, fabrication dependent three dimensional surface topography consisting of regular or non-regular micrometer and nanometer sized features. Surface properties are related both to molecular interactions and the surface topography (Barthlott and Neinhuis, 1997). The difference in surface properties may then have profound effects on the protein adhesion and the following cellular attachment.

\section{Surface Effects on Biological Phenomena}

The term 'basic reactions of osteoblasts on material surfaces' covers in a time related manner different phenomena: protein adsorption at the material surface, followed by the attachment phase which occurs rapidly and involves short-term events. Physico-chemical interactions between cells and materials involving ionic forces, van der Waals forces, and other forces govern this attachment process. The adhesion phase follows the attachment phase. Osteoblast adhesion on material surfaces occurs in the longer term and involves various biological molecules interacting together to induce signal transduction and consequently regulating the subsequent cell response. It is important to note that the mentioned steps describe the cell reaction in an idealised manner, whereas in reality they are complex and interconnected.

\section{Protein Adsorption}

Cells do not interact with a naked material either in vitro or in vivo. At each step, the material is conditioned by the biological fluid components (for review see Elwing, 1998). The $\mathrm{pH}$ as well as the ionic composition and strength of solution, temperature and the functional group of proteins and substrates are the factors determining protein adsorption (Vroman effect: Vroman, 1987). Protein adsorption is believed to be a very early event that takes place after contact of body fluids with artificial surfaces. Small rapidly diffusing proteins attach early after substrate/protein interaction at the surfaces, but are then replaced by larger proteins with high affinity to the surface. Some of the bone proteins have chemotactic or adhesive properties, notably because they contain an Arg-Gly-Asp (RGD) sequence which is specific to the fixation of cell membrane integrin receptors. Various in vitro experiments have demonstrated the importance of isolated RGD-sequence containing peptides (fibronectin, vitronectin) in promoting adhesion of bone cells (Meyer et al., 1998; Moursi et al., 1997) exerting also strong effects on matrix maturation and mineralisation (Rezania and Healy, 2000).

\section{Material Characteristics/Cell Interaction}

Different material properties have been proposed as influencing the biological response. The surface topography and the physico-chemical surface characteristics are the most important parameters. The relationship between the topographical and physicochemical properties of materials and their effect on the protein adsorption followed cellular activity is, as mentioned, complex and generally not solved. Cells act with surfaces in several ways, directly and indirectly. Oxygen tension and other parameters act on cells in culture in a complex manner. It is widely accepted that the topography and chemistry of the surface of an implant to a large extent determine the biological reaction to the device, but there is little information on how these factors interact in the production of biological responses. The lack of knowledge is based to a great extent from the difficulty in varying surface chemistry and topography independently. Only a few studies were performed to investigate the relation between surface topography and surface chemistry. A direct relationship for example was found between roughness and surface energy of polymethylmetacrylate (PMMA) materials (Combe et al., 2004). The complex and sometimes unknown or undetermined interrelations between topographical and physio-chemical properties of materials make the comparison of cellular in-vitro findings difficult, especially in light of the consideration that both 
parameters have an influence on protein and cell adherence at the same time (Scotchford et al., 2003). The following description of bone cell culture findings towards material topography and surface chemistry should be seen in consideration of the above mentioned limitations.

\section{Surface topography}

One of the most important parameters affecting osteoblast reactivity is the three-dimensional morphology of the substrate. The three-dimensional morphology can be conceptualised as the size, the shape and the surface texture of the material. Various studies (Dalby et al., 2000) demonstrated that bone cells are sensitive to the gross morphology of a material but difficulty exists on interpreting the present data due to a lack of comparable studies. When examining the behaviour of osteoblast-like cells on surfaces with different roughness, controversial findings were reported. The differences found in osteoblast behaviour towards different surface topographies may partly be based on the different cell lines used for the surface testings as some authors used primary (Jayaraman et al., 2004) and others osteosarcoma cell lines (Martin et al., 1995). More importantly, it is difficult to compare the in vitro findings on osteoblast behaviour on surfaces with different topographies because there is no consensus concerning the proper representation of implant surface topography (Cooper, 2000). Many different surfaces are categorized as 'rough' or 'smooth', a system that has segregated machined material surfaces from others. The main misunderstanding is the practice of defining a surface by its manufacturing process instead of concisely define the topographic measurements (Macdonald et al., 2004). Most of these surface roughness investigations evaluated the osteoblast behaviour on micro structured surfaces (Curtis and Clark, 1990; Curtis and Wilkinson, 1997), but recent research emphasises that in addition to the micro topography, cells use the nano topography of the substrate for orientation and migration (Curtis and Wilkinson, 2001; Dalby et al., 2000; Wang et al., 2000). The relevance of the older (macro structure) studies to the osteoblast behaviour in vivo is questionable since in vivo adhesion structures (e.g. cell membranes, basement membranes) are comprised of much smaller nanometer scale features (Webster et al., 2000). Whereas it was generally accepted that various cell types, like osteoblasts, align themselves along defined substrate morphologies inscribed on culture surfaces (Domke et al., 2000), a process known as contact guidance, the relation between ordered nano topography and cell behaviour is to a great extent unknown. In 1941 Paul Weiss wrote about his hypothesis of contact action or guidance where a microscopic body (in his study nerve fibres) can follow an ultramicroscopic interface with its terminal pseudopodia. He stated that any ultrastructural orientation of the medium, no matter how attained, may have some effect on the nerve fibres. In 1964 Curtis and Varde showed substrate topography also has controls, convex surfaces enhancing overlap and grooves minimising overlap. Recent investigations on ordered nanostructured surfaces, fabricated according to the method described by Gleiche et al. (2000), reveal that

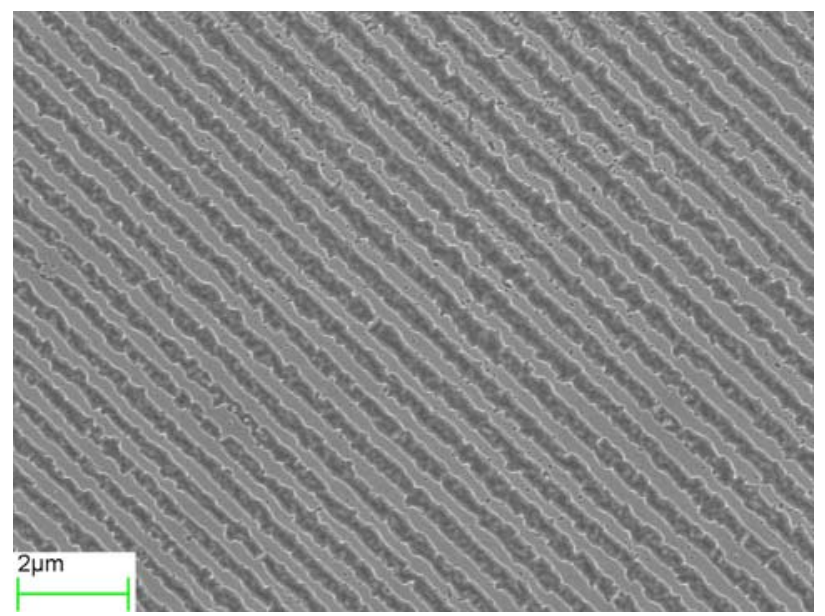

Figure 2: Fabrication of highly ordered nanostructures over extended areas by Langmuir-blodgett transfer (bar indicates magnification).

structured nanophase surfaces lead to a predictable osteoblast orientation and migration on these surfaces (Lenhert et al., 2004), a prerequisite to reach a defined cell colonisation during directed tissue formation (Figure 2). Numerous studies have demonstrated that cell shape and orientation are related to gene expression, and changes in cell shape that follow cell adhesion on material surfaces by alterations in cell-extracellular matrix contacts are associated with changes in the differentiated phenotype of cells. These alterations in cell shape are associated with cytoskeletal changes that may affect much of a cell's metabolism (Martines et al., 2004). How cells respond to these structures is probably due to actin- myosin tension structures of cells. Cells produce significant amount of tension and primary osteoblasts in culture produce larger amounts of tension than it was shown for other cells.

\section{Surface Chemistry}

It is well known that cells are also sensitive to differences in the physico-chemical properties of materials. Differences in the chemistry of the outer most functional groups of a surface clearly affect cell responses, although the exact mechanisms are not fully understood (Schwartz and Boyan, 1994). Anisotropic topographies, such as topographical grooves, chemically patterned stripes, or the curved surface of a fibre are known to exert morphological as well as physico-chemical features on cells at the same time, indicative for the complex environmental influence on cells. Important physico-chemical characteristics of surfaces are the zeta potential and the interfacial tension. The zeta potential is defined as the differences in potentials between the surface of a tightly bound layer and a diffuse layer. It was found that osteoblasts are most likely influenced by the properties of the surface charge (Möller et al., 1994). The interfacial tension or wettability as an additional influencing parameter is measured as a property of the interaction forces (or adhesion forces) between different materials and their interaction with the cohesion forces within the materials (Andrade, 1973). Möller et al. (1994) investigated the relation between attachment and 


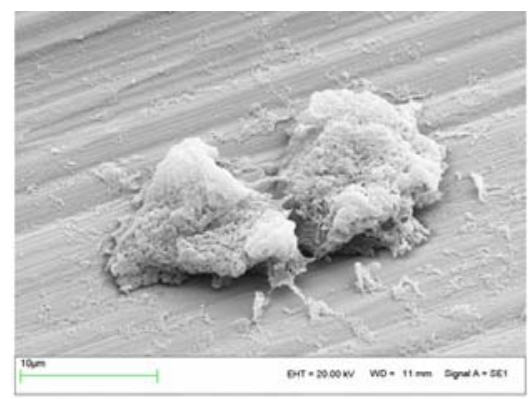

a)

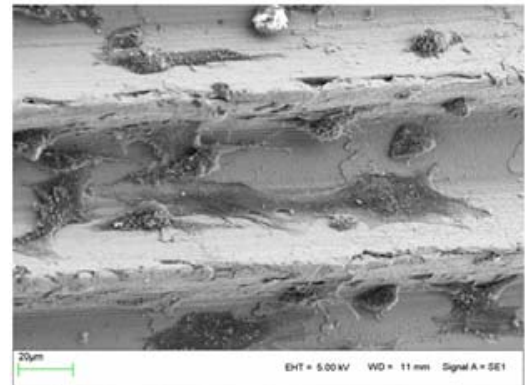

d)

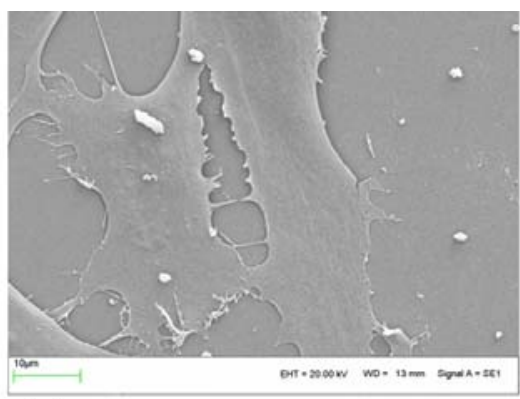

b)

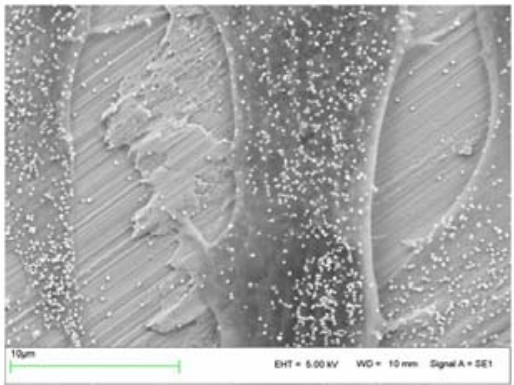

e)

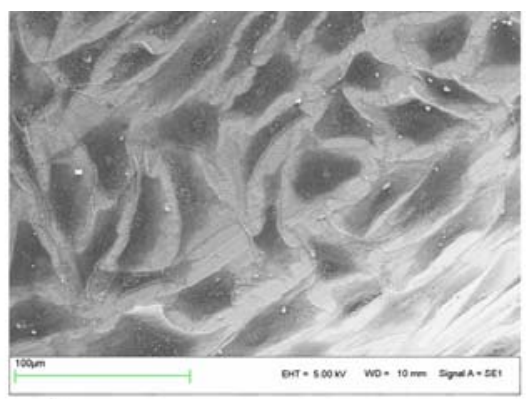

c)

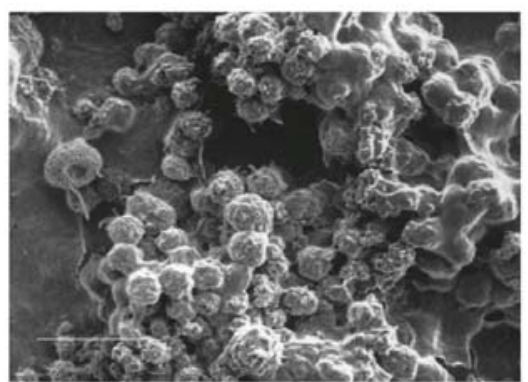

f)

Figure 3: Stages of osteoblast/titanium surface interaction. Scanning electron microscopy (bar indicates magnification). A) Cell attachment, b) cell spreading, c) cell proliferation, d) cell migration, e)matrix synthesis (immune staining of osteonectin) and f) mineral formation (bar $1 \mu \mathrm{m}$ ).

proliferation of osteoblasts and biomaterials with different wettability but found no direct correlation between the wettability of the material surface and the osteoblast reaction towards the material. Recent investigations (Redey et al., 2000) revealed that low osteoblast cell attachment and collagen production were related to a low wettability of substrates. They suggested that an enhancement of polar components of the surface improves cell attachment and matrix synthesis. All investigations reveal that a change in surface chemistry has significant sequel with respect to osteoblast function, but direct correlations between distinct parameters and cell function are not entirely cleared, due to problems in processing surfaces with defined surface chemistry and topography (Liao et al., 2003). The element composition of the material surface was found to have also distinct effects on osteoblast behaviour (Zreiquat and Howlett, 1999; DiSilvio et al., 2002). The observed differences between cell behaviour on pure titanium or titanium alloys is known, but the underlying mechanisms are not well known. It has not yet been solved whether the presence of elements in the material or the ion release of such materials affects cell behaviour (Meyer et al., 1993; Matsuoka et al., 1999; Loty et al., 2000).

\section{Cell Adhesion, Migration and Proliferation}

The physico-chemical driven attachment of osteoblasts with surfaces has therefore profound effects on the subsequent cell adhesion, followed by proliferation, migration and phenotypic differentiation (Figure 3). Osteoblasts adhere to artificial substrates through adhesion molecules (Meyer et al., 1997), contact sites which are classified depending on the distance of the cell from the substrate (Chen and Singer, 1982). The cell-matrix adhesions mechanically connect the internal actin filaments to the matrix. The complex is known as a focal adhesion, focal plaque or focal contact. Contacts between cells and solids were first observed using the surface contact light microscope (Ambrose, 1956) and their distance of closest approach to the surface was found to be approximately $10 \mathrm{~nm}$ using interference reflection microscopy (IRM) (Curtis, 1964). Using this technique, it indicated that there is no extracellular material between the cells and glass in the adhesions. No fragments were observed using IRM, when the cells de-adhere from the glass and the adhesions were observed to be confined to cell edges and pseudopods. It was not until the late sixties that a transmission electron microscope (TEM) was used to observe cell contacts (Cornell, 1969), confirming their distance of closest approach. Izzard and Lochner (1976) studied cell-substrate contacts using IRM and found that focal contacts occur linearly beneath the associated cytoplasmic stress fibres. These are equivalent to the amorphous electron dense material and oriented microfilaments described by Abercrombie and co-workers (1971). Using chick fibroblasts the technique was used to identify three types of separation. They are: focal adhesions appearing black and corresponding to approximately $10-15 \mathrm{~nm}$ separation from the substrate under the peripheral regions of the 
leading lamellae; close contacts of broader grey areas, corresponding to approximately $30 \mathrm{~nm}$ separation; and white regions of greater separation, corresponding to approximately 100-140nm. Richards and co-workers showed in 1995 that shear forces of the impingement on materials were seen to be greater than the cohesive strength of the cells in the impinged area, causing their rupture. The cell bodies were removed during impingement, leaving the sites of adhesion and other cellular material behind. Close examination of the areas of detached cells revealed "ghosts" where some of the cells were attached before impingement. These "ghosts" on higher magnification were seen to be remnants of the lower surface adhesions and membranes of the detached cells. Focal contacts are therefore tenacious adhesion sites that remain attached to the substratum even when cells are forcibly detached, indicating their function as anchorage structures (Balaban et al., 2001). The external faces of focal contacts present specific receptor proteins such as integrins. They act as an interface between the intra- (cytoskeleton) and extracellular (matrix proteins) compartment. The cytoskeletal proteins are assumed to be the most important intracellular structures responsible for the intracellular part of cell attachment and for signal transduction (for review see Jones et al., 1995, Krause et al., 2000).

It was shown by different investigators, that tissue responses at material surfaces are related to the integrin related cell adhesion (Kay et al., 2002; Liu et al., 2001; Meyer et al., 1998; Price et al., 2003; Zinger et al., 2003) Cell proliferation and migration is the attachment following phase between the cell and the material surface (for review see Anselme, 2000). Concerning cell attachment and migration it was found that osteoblasts settled on smoother surface tend to spread out, forming greater number of focal contacts (Jayaraman et al., 2004). In general, cells with a low motility form strong focal adhesions while motile cells form less adhesive structures. An intermediate level of attachment force induces a maximal migration rate. Also, a high migration rate is associated with a lower level of osteoblast differentiation.

\section{Matrix Formation and Mineralisation}

The expression of the final stages of osteogenic differentiation on biomaterial surfaces implies the production of an osteoid-like matrix (Plate et al., 1998, Wiesmann et al., 2003). It is known that the newly formed mineral in bone and in cell culture is based on the synthesis of mineral spherites. The mineral spherites are likely to be present at the initiation sites of mineral formation in vivo as well as in vitro cultures. Osteoblast culture models as well as non-cellular models have demonstrated the potential effect of nanostructured surface characteristics on mineralising matrix formation (Catledge et al., 2002; Hartgerink et al., 2001) but one limitation of interpretation of these data is the lack of analytical data concerning the surface structure as well as the mineral structure (Linhart et al., 2001). It is also important to note that some controversies exist about mineralisation in cell culture systems. It is to date not finally solved whether the presented mineralisation processes are culture artefacts or not, especially because in cell culture, matrix vesicle mediated mineralisation is not followed by collagen mineralisation (Wiesmann et al., 2003).

\section{Functional Aspects of Osteoblast/Surface Interactions}

In order to conceptionalise long term reactions it is important to recognise that cells are not only influenced by the material itself but also by the biophysical constraints of the material surface under function. This is obvious in directly loaded implants (dental implants, osteosynthesis plates) but also present at the material interface in functionally loaded locations (Meyer et al., 2003). The application of non-destructive physiological and hyperphysiological in vitro mechanical constraints to the cell/material interface permits understanding of biophysical effects on the synthesis of adhesion proteins, cell growth and cell differentiation (Büchter et al., 2005a). The biophysical mechanisms underlying the cell response at material surfaces may include direct or indirect mechanical effects (Frost, 2000), electromechanical effects (Pienkowski and Pollack, 1983), or enhancement of molecular transport mechanisms (Piekarski and Munro, 1977). Osteoblasts can sense small deformations that arise on the surface of biomaterials as a result of mechanical loading (Jones et al., 1991). Therefore, load transfer from material surfaces to osteoblasts may have profound effects on cell behaviour. In presence of deformations at the biomaterial surface forces will be pertubed by the osteoblasts through the attachment sites (Jones et al., 1995). Mechanical stimulation was shown to result in an altered expression of alkaline phosphatase, osteopontin, osteocalcin, and collagen type I and an enhancement of proliferative activity (Klein-Nulend et al., 1997, Hillsley and Frangos, 1997; Harter et al., 1995). As mechanical stimulation is able to promote tissue formation in vitro (Jones et al., 2003), a new approach is the development of "mechano-active" biomaterials with optimised inherent physical properties (Wiesmann et al., 2004; Yang et al., 2002). Surface deformations leads not only to a deformation of cells in the microenvironment of the tissue but simultaneously also to a fluid flow related generation of electrical potentials (Büchter et al., 2005b). Many experiments in this field of research have evaluated the effect of electrical fields on bone cell behaviour (Fukada and Yasuda, 1957), but the mechanism of electric cell modification at material surfaces is not completely understood. Recent investigations demonstrated that the presence of electric fields has distinct effects on osteoblasts in vitro (Hartig et al., 2000). Furthermore, electrical effects on osteoblast cell cultures in long term experiments were well suited to alter the cascade of biochemical processes at artificial surfaces resulting in a newly formed extracellular matrix which leads to improved biomineral formation (Wiesmann et al., 2001). 


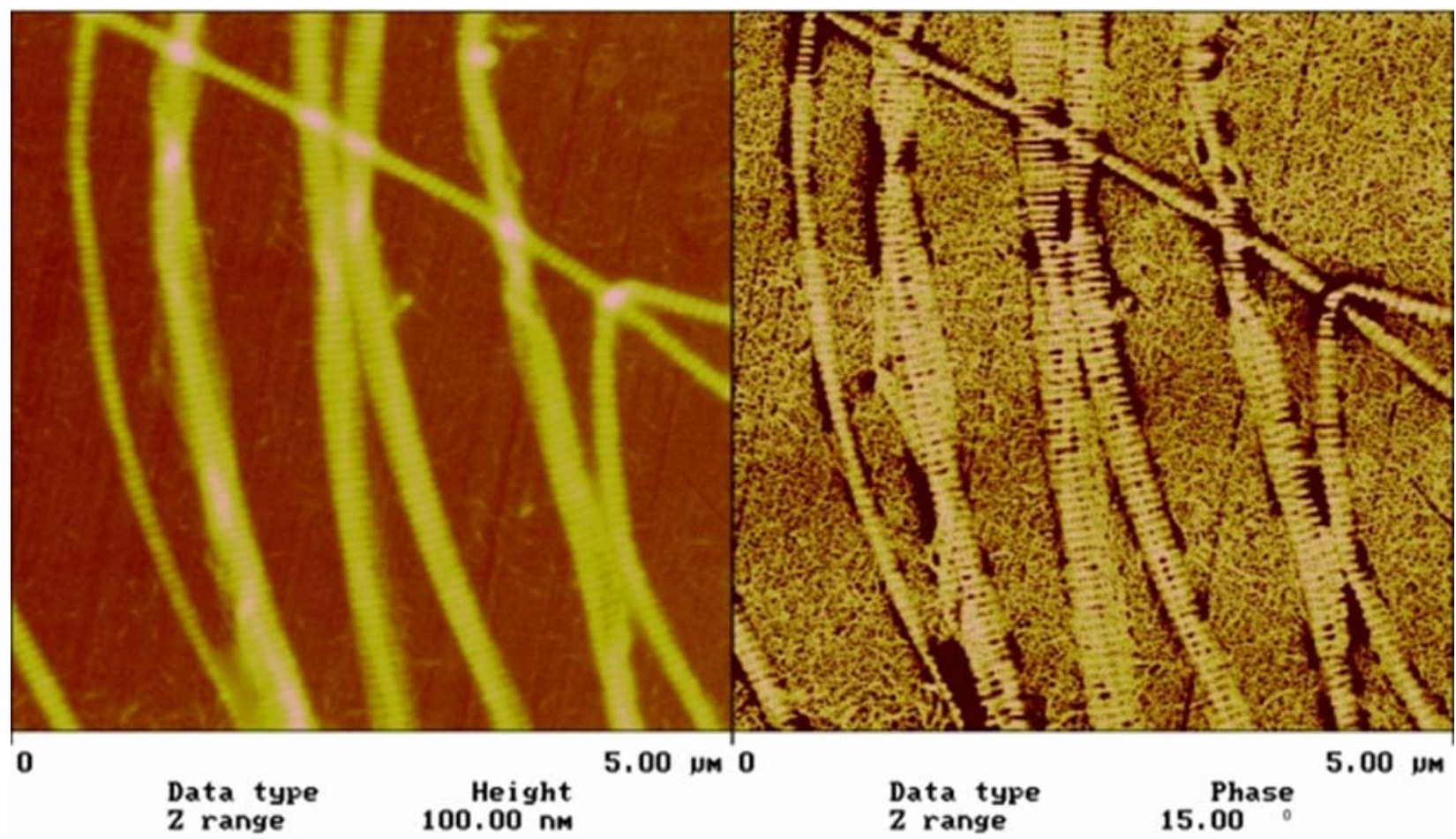

\subsection{8}

Figure 4: Collagen adhesion on titanium surface (Atomic force microscopy).

\section{Discussion and Perspectives}

Biomaterial and material related biomolecular engineering strategies focus to increase the biofunctional activity and therefore represent promising strategies for the engineering of robust biofunctional devices (Jung et al., 2001).

\section{Clinical aspect}

In order to improve clinically used materials, it must be recognized what is known about the in-vivo effect of structured biomaterials on bone. It is not clear whether invitro evaluations are predictive of or correlated with in vivo outcomes, because the in vivo effect of surface topography and chemistry on the nature of the adherent cell population, its diversity, its activity, and its clinical relevance has for none of the biomaterials been fully elucidated. Based on the current knowledge of basic osteoblast reactions on structured materials, patterning material surfaces, surface alteration of materials by selectively adsorb adhesion peptides, coating of surfaces with proteins or growth factors, and imprinting surfaces with genome containing vectors are current approaches to 'activate' biomaterial surfaces (Garcia and Keselowski, 2002).

\section{Surface patterning}

As novel advances in material processing techniques enable to produce surface topographies below a micro scale level (Scotchford et al., 2003), a number of studies have begun to assess the response of various cellular phenotypes to nanotopography surfaces (Curtis and Wilkinson, 1999). A review of these studies indicates that different cell phenotypes have different levels of sensitivity (Dalby et al., 2002; Curtis et al., 2001). Osteoblasts were shown to react to features as low as to the $10 \mathrm{~nm}$ dimension, a width that is comparable to a single collagen fibre (Rice et al., 2003). Only a limited number of studies evaluated the in vivo effects of nanotopographies in respect to bone healing. Hallgren and colleagues (2001) for example revealed no statistically significant differences in the histomorphometric or biomechanical results between the nano patterned and control implants.

\section{Peptide/Protein adhesion}

Based on the knowledge that protein adsorption on surfaces influences the cell adhesion behaviour, selective coating of surfaces with proteins offer improvements of osteoblast behaviour on artificial surfaces (Figure 4; Zhang et al., 2002). Different techniques were used to deposit proteins at nano structured surfaces (Sarikaya et al., 2003; Biebuyck and Whitesides, 1994; Gau et al., 1999; Kim et al., 1995; Xia and Whitesides, 1998). Whereas attempts to imprint defined peptides have met with only limited success, Shi et al. (1999) reported in a recent study on a new method for imprinting surfaces with specific protein-recognition sites. The identification of recognition sequences, such as RGD or fibronectin (FN) fragments, that mediate cell adhesion has stimulated the development of adhesive surfaces (Cutler and Garcia, 2003) Adherent cells spread and assembled focal adhesions containing, vinculin, and talin on these surfaces, but the cell adhesion was not associated with a subsequent enhancement of cellular functions. Among the proteins collagen is a main candidate for surface coatings (Nagei et al., 2002; Schliephake et 
al., 2004; Rammelt et al., 2004), followed by bone sialoprotein coatings (O'Toole et al., 2004). Various growth and differentiation factors, notably members of the Transforming Growth Factor- family (TGF- PDGF, BMP2, BMP-7, IGF) are being now studied as material coatings in order to improve bone healing (Hartwig et al., 2003; Esenwein et al., 2003; Kandziora et al., 2002). Growth factors coaxed with materials have experimentally shown that they retain their biological activity (Liu et al., 2004) but it is up until recently unknown whether these proteins may improve implant healing in vivo. Coaxing of material surfaces with genome sequences is a future perspective (Thorwarth et al., 2004) in an effort to improve biomaterial surfaces, but the immanent biological, legal and ethical aspects have to be solved before this approach can be used in clinical trials.

\section{Conclusion}

A variety of claims are made regarding the effect of surface structure on enhancing the performance of bone biomaterials, but many in vitro and in vivo experimental observations have key limitations in their interpretations. Additional basic research regarding the relationship of defined ordered surface topography and chemistry to cell and tissue behaviour is needed to better define surfaces that can improve the behaviour of bone at biomaterials.

\section{Acknowledgements}

The authors acknowledge with thanks the financial support provided by the German Research Foundation (DFG) and by Innovative Medical Research (IMF, University of Münster, Germany).

\section{References}

Abercombrie M, Heaysman JE, Pegrum SM (1971) The locomotion of fibroblasts in culture. IV. Electron microscopy of the leading lamella. Exp Cell Res 67: 359367.

Andrade JD (1973) Interfacial phenomena and biomaterials. Med Instr 7: 110-113.

Anselme K (2000) Osteoblast adhesion on biomaterials. Biomaterials 21: 667-681.

Ambrose EJ (1956) A surface contact microscope for the study of cell movements. Nature 178: 1194.

Aubin JE (1998) Advances in the osteoblast lineage. Biochem Cell Biol 76: 899-910.

Balaban NQ, Schwarz US, Riveline D, Goichberg P, Tzur G, Sabanay I, Mahalu D, Safran S, Bershadsky A, Addadi L, Geiger, B (2001) Force and focal adhesion assembly: A close relationship studied using elastic micropatterned substrates. Nat Cell Biol 3: 466-472.

Barthlott W, Neinhuis C (1997) Purity of the sacred lotus, or escape from contaminations in biological surfaces. Planta 202: 1-8.
Biebuyck HA, Whitesides GM (1994) Selforganisation of organic liquids on patterned self-assembled monolayers of alkanthiols on gold. Langmuir 10: 27902793.

Boyan BD, Hummert TW, Dean DD, Schwartz Z (1996) Role of material surfaces in regulating bone and cartilage cell response. Biomaterials 17: 137-146.

Büchter A, Kleinheinz J, Wiesmann HP, Kersken J, Joos U, Meyer U (2005a) Biological and biomechanical evaluation of bone remodelling and implant stability after using an osteotome technique. Clin Oral Impl Res 16: 1-8

Büchter A, Wiechmann D, Koerdt S, Wiesmann HP, Piffko J, Meyer U (2005b) Load related implant reaction of mini-implants used for orthodontic anchorage. Clin Oral Impl Res (in press)

Burg KJL, Porters S, Kellam JF (2000) Biomaterial developments for bone tissue engineering. Biomaterials 21: 2347-2359.

Burger EH, Klein-Nulend J, van der Plas A, Nijweide PJ (1995) Function of osteocytes in bone-their role in mechanotransduction. J Nutr 125: 2020-2023.

Catledge SA, Fries MD, Vohra YK, Lacefield WR, Lemons JE, Wood S, Venugopalan R (2002) Nanostructured ceramics for biomedical implants. J Nanosci Nanotechnol 2: 293-312.

Chen WT, Singer SJ (1982) Immunoelectron microscopic studies of the sites of cell-substratum and cellcell contacts in cultured fibroblasts J Cell Biol 95: 205222.

Coelho MJ, Fernandes MH (2000) Human bone cell cultures in biocompatibility testing. Part II: effect of ascorbic acid, beta-glycerophosphate and dexamethasone on osteoblastic differentiation. Biomaterials 21: 10951102.

Combe EC, Owan BA, Hodges JS (2004) A protocol for determining the surface free energy of dental materials. Dent Mater 20: 262-268.

Cooper LF, Masuda T, Yliheikkila PK, Felton DA (1998) Generalizations regarding the process and phenomenon of osseointegration. Part II. In vitro studies. Int J Oral Maxillofac Impl 13: 163-174.

Cooper LF (2000) A role for surface topography in creating and maintaining bone at titanium endosseous implants. J Prosthet Dent 84: 522-534.

Cornell R (1969) Cell substrate adhesion during cell culture. Exp Cell Res 58: 289-295.

Curtis ASG (1964) The mechanism of adhesion of cells to glass. A study by interference reflection microscopy. J Cell Biol 20: 199-215.

Curtis ASG, Varde M (1964) Control of cell behaviour: topological factors. J Natl Cancer Inst 33: 15-26.

Curtis ASG, Clark P (1990) The effects of topographic and mechanical properties of materials on cell behaviour. Crit Rev Biocompatibility 5: 343-362.

Curtis ASG, Wilkinson C (1997) Topographical control of cells. Materials 18: 1573-1583.

Curtis ASG, Wilkinson C (1999) New depths in cell behaviour: reactions of cells to nanotopography. Biochem Soc Symp 65: 15-26.

Curtis ASG, Casey B, Gallagher JO, Pasqui D, Wood 
MA, Wilkinson CD (2001) Substratum nanotopography and the adhesion of biological cells. Are symmetry or regularity of nanotopography important Biophys Chem 94: 275-283.

Curtis ASG, Wilkinson C (2001) Nanotechniques and approaches in biotechnology. Trends Biotechnol 19: $97-$ 101.

Cutler SM, Garcia AJ (2003) Engineering cell adhesive surfaces that direct integrin alpha5betal binding using a recombinant fragment of fibronectin. Biomaterials 24: 1759-1770.

Dalby MJ, Di Silvio L, Davies GW and Bonfield W (2000) Surface topography and HA filler volume effect on primary human osteoblasts in vitro J Mat Sci: Mater Med 11: 805-810.

Dalby MJ, Yarwood SJ, Riehle MO, Johnstone H, Affrossman S, Curtis, ASG (2002) Increasing fibroblast response to materials using nanotopography: Morphological and genetic measurements of cell response to $13 \mathrm{~nm}$ high polymer demixed islands. Exp Cell Res 276: 1-9.

Davies JE, Causton B, Bovell Y, Davy K, Sturt CS (1986) The migration of osteoblasts over substrata of discrete surface charge. Biomaterials 7: 231-233.

Davies JE, Lowenberg B, Shiga A (1990) The bonetitanium interface in vitro. J Biomed Mater Res 24: 1289-1306.

Di Silvio L, Dalby MJ, Bonfield W (2002) Osteoblast behaviour on HA/PE composite surfaces with different HA volumes. Biomaterials 23: 101-107.

Domke J, Dannohl S, Parak WJ, Muller O, Aicher WK, Radmacher M (2000) Substrate dependent differences in morphology and elasticity of living osteoblasts investigated by atomic force microscopy. Colloids Surf B Biointerfaces 30: 367-379.

Elgendy HM, Norman ME, Keaton AR, Laurencin CT (1993) Osteoblast-like cell (MC3T3-E1) proliferation on bioerodible polymers: an approach towards the development of a bone-bioerodible polymer composite material. Biomat. 14: 263-269.

Elwing H (1998) Protein absorption and ellipsometry in biomaterial research. Biomaterials 19: 397-406.

Esenwein SA, Esenwein S, Herr G, Muhr G, Kusswetter W, Hartwig CH (2003) Histologic and histomorphometric follow-up observations of osseointegration of corundumblasted BMP-3 coated titanium test implants (Ti6Al4V) at orthotopic site in the giant rabbit. Biomed Tech (Berl). 48: 217-224.

Frost HM (2000) The Utah paradigm of skeletal physiology: An overview of its insights for bone, cartilage and collagenous tissue organs. J Bone Miner Metab 18: 305-316.

Fukada E and Yasuda I (1957) On the piezoelectric effect of bone. J Phys Soc Japan 12: 1158-1162.

Garcia AJ, Keselowsky BG (2002) Biomimetic surfaces for control of cell adhesion to facilitate bone formation. Crit Rev Eukaryot Gene Expr 12: 151-162.

Gau H, Herminghaus S, Lenz P, Lipowsky R (1999) Liquid morphologies on structured surfaces: from microchannels to microchips. Science 283: 46-49.
Gleiche M, Chi LF, Fuchs H (2000) Nanoscopic channel lattices with controlled anisotropic wetting. Nature 403: 173-175.

Grigordias AE, Heersche JN, Aubin JE (1990) Continuously growing bipotential and monopotential myogenic, adipogenic, and chondrogenic subclones isolated from the multipotential RCJ 3.1 clonal cell line. Dev Biol 142: 313-318.

Hallgren C, Reimers H, Gold J, Wennerberg A (2001) The importance of surface texture for bone integration of screw shaped implants: An in vivo study of implants patterned by photolithography J Biomed Mater Res 57: 485-496.

Harter LV, Hruska KA, Duncan RL (1995) Human osteoblast-like cells respond to mechanical strain with increased bone matrix protein production independent of hormonal regulation. Endocrinology 136: 528-35.

Hartgerink JD, Beniash E, Stupp SI (2001) Selfassembly and mineralization of peptide-ampiphile nanofibers. Science 294: 1684-1688.

Hartig M, Joos U, Wiesmann HP (2000) Capacitively coupled electric fields accelerate proliferation of osteoblast-like primary cells and increase bone extracellular matrix formation in vitro. Eur Biophys J 29: 499-506.

Hartwig CH, Esenwein SA, Pfund A, Kusswetter Dagger W, Herr G (2003) Improved osseointegration of titanium implants of different surface characteristics by the use of bone morphogenetic protein (BMP-3): an animal study performed at the metaphyseal bone bed in dogs. Z Orthop Ihre Grenzgeb 141: 705-711.

Hillsley MV, Frangos JA (1997) Alkaline phosphatase in osteoblasts is down-regulated by pulsatile fluid flow. Calcif Tissue Int 60: 48-53.

Hutmacher DW (2000) Scaffolds in tissue engineering bone and cartilage. Biomaterials 21: 2529-2543.

Izzard CS, Lochner LR (1976) Cell to substrate contacts in living fibroblasts: an interference reflexion study with an evaluation of the technique. J Cell Sci 21: 129-159.

Jayaraman M, Meyer U, Bühner M, Joos U, Wiesmann HP (2004) Influence of titanium surfaces on attachment of osteoblast-like cells in vitro. Biomaterials 25: 625-631.

Jones DB, Nolte H, Scholubbers JG, Turner E, Veltel D (1991) Biochemical signal transduction of mechanical strain in osteoblast-like cells. Biomaterials 12: 101-109.

Jones D, Leivseth G, Tenbosch J (1995) Mechanoreception in osteoblast-like cells. J Biochem Cell Biol 73: 525-532.

Jones DB, Broeckmann E, Pohl T, Smith EL (2003) Development of a mechanical testing and loading system for trabecular bone studies for long term culture. Eur Cells Mater 5: 48-60.

Jung DR, Kapur R, Adams T, Giuliano KA, Mrksich M, Craighead HG, Taylor DL (2001) Topographical and physicochemical modification of material surface to enable patterning of living cells. Crit Rev Biotechnol 21: 111154.

Kandziora F, Schmidmaier G, Schollmeier G, Bail H, Pflugmacher R, Gorke T, Wagner M, Raschke M, Mittlmeier T, Haas NP (2002) IGF-I and TGF-beta1 
application by a poly-(D,L-lactide)-coated cage promotes intervertebral bone matrix formation in the sheep cervical spine. Spine 27: 1710-1723.

Kay S, Thapa A, Haberstroh KM, Webster TJ (2002) Nanostructured polymer/nanophase ceramic composites enhance osteoblast and chondrocyte adhesion. 8: 753-761.

Kim E, Xia Y, Whitesides GM (1995) Polymer microstructures formed by moulding in capillaries. Nature 376: 581-584.

Klein-Nulend J, Roelofsen J, Semeins CM, Bronckers AL, Burger EH (1997) Mechanical stimulation of osteopontin mRNA expression and synthesis in bone cell cultures. J Cell Physiol 170: 174-181.

Krause A, Cowles EA, Gronowicz G (2000) Integrinmediated signaling in osteoblasts on titanium implant materials. J Biomed Mater Res 52: 738-747.

Lenhert S, Meier MB, Meyer U, Chi L, Wiesmann HP (2004) Osteoblast alignment, elongation and migration on grooved polystyrene patterned by Langmuir-Blodgett lithography. Biomat. 26: 563-570.

Liao H, Andresson AS, Sutherland D, Petronis S, Kasemo B, Thomsen J (2003) Response of rat osteoblastlike cells to microstructured modified surfaces in-vitro. Biomaterials 24: 645-654.

Linhart W, Peters F, Lehmann W, Schwarz K, Schilling AF, Amling M, Rueger JM, Epple M (2001) Biologically and chemically optimized composites of carbonated apatite and polyglycolide as bone substitution materials. J Biomed Mater Res 54: 162-171.

Liu J, Zhang Q, Remsen EE, Wooley KL (2001) Nanostructured materials designed for cell binding and transduction. Biomacromolecules 2: 362-368.

Liu Y, Hunziker EB, Layrolle P, De Bruijn JD, De Groot K (2004) Bone morphogenetic protein 2 incorporated into biomimetic coatings retains its biological activity. Tissue Eng. 10: 101-108.

Loty C, Sautier JM, Boulekbache H, Kokubo T, Kim HM, Forest N (2000) In vitro bone formation on a bonelike apatite layer prepared by a biomimetic process on a bioactive glass-ceramic. J Biomed Mater Res 15: 423434.

Macnair R (1997) The response of primary rat and human osteoblasts and an immortalized rat osteoblast cell line to orthopaedic materials: comparative sensitivity of several toxicity indices. J Mat Sci: Mater Med 8: 105-111.

Martin JY, Schwartz Z, Hummert TW, Schraub DM, Simpson J, Lankford Jr. J, Dean DD, Cochran DL, Boyan BD (1995) Effect of titanium surface roughness on proliferation, differentiation and protein synthesis of human osteoblast-like cells (MG 63). J Biomed Mat Res 29: 389-401.

Martines E, McGhee K, Wilkinson C, Curtis A (2004) A parallel-plate flow chamber to study initial cell adhesion on a nanofeatured surface. IEEE Trans Nanobioscience 3: 90-95.

Matsuoka H, Akiyama H, Okada Y, Ito H, Shigeno C, Konishi J, Kokubo T, Nakamura T (1999) In vitro analysis of the stimulation of bone formation by highly bioactive apatite- and wollastonite-containing glass-ceramic: released calcium ions promote osteogenic differentiation in osteoblastic ROS17/2.8 cells. J Biomed Mater Res 47: 176-188.

Macdonald W, Campbell P, Fisher J, Wennerberg A (2004) Variation in surface texture measurements. J Biomed Mater Res 15: 262-269.

Meyer U, Szulczewski DH, Barckhaus RH, Atkinson M, Jones DB (1993) Biological evaluation of an ionomeric bone cement by osteoblast cell culture methods. Biomaterials 14: 917-922.

Meyer U, Meyer T, Jones DB (1997) No mechanical role for vinculin in strain transduction in primary bovine osteoblasts. Biochem Cell Biol 75: 81-87.

Meyer U, Meyer T, Jones DB (1998) Attachment kinetics, proliferation rates and vinculin assembly of bovine osteoblasts cultured on different pre-coated artificial substrates. J Mat Sci: Mat Med 9: 301-307.

Meyer U, Wiesmann HP, Fillies T, Joos U (2003) Early tissue reaction at the interface of immediate loaded dental implants. Int J Oral Maxillofac Impl 18: 489-499.

Meyer U, Joos U, Wiesmann HP (2004a) Biological and biophysical principles in extra corporal bone tissue engineering -Part I-. Int J Oral Maxillofac Surg 33: 325332.

Meyer U, Joos U, Wiesmann HP (2004b) Biological and biophysical principles in extra corporal bone tissue engineering -Part III., Int J Oral Maxillofac Surg 33: 635641.

Möller K, Meyer U, Szulczewski DH, Heide H, Priessnitz B, Jones DB (1994) The influence of zeta potential and and interfacial tension on osteoblast-like cells. Cells and Materials 4: 263-268.

Moursi AM, Globus RK, Damsky CH (1997) Interactions between integrin receptors and fibronectin are required for calvarial osteoblast differentiation in vitro. $\mathrm{J}$ Cell Sci 110: 2187-2196.

Nagai M, Hayakawa T, Fukatsu A, Yamamoto M, Fukumoto M, Nagahama F, Mishima H, Yoshinari M, Nemoto K, Kato T (2002) In vitro study of collagen coating of titanium implants for initial cell attachment. Dent Mater J 21: 250-260.

Oreffo RO and Triffitt JT (1999) Future potentials for using osteogenic stem cells and biomaterials in orthopedics. Bone 25: 5-9.

O'Toole GC, Salih E, Gallagher C, FitzPatrick D, O’Higgins N, O’Rourke SK (2004) Bone sialoproteincoated femoral implants are osteoinductive but mechanically compromised. J Orthop Res 22: 641-646.

Owen TA, Aronow M, Shalhoub V, Barone LM, Wilming L, Tassinari MS, Kennedy MB, Pockwinse S, Lian JB, Stein GS (1990) Progressive development of the rat osteoblast phenotype in vitro: reciprocal relationships in expression of genes associated with osteoblast proliferation and differentiation during formation of the bone extracellular matrix. J Cell Physiol 143: 420-430.

Piekarski K, Munro M (1977) Transport mechanism operating between blood supply and osteocytes in long bones. Nature 269: 80-82.

Pienkowski D, Pollack SR (1983). The origin of stressgenerated potentials in fluid-saturated bone. J Orthop Res 1: $30-41$. 
Plate U, Arnold S, Stratmann U, Wiesmann HP, Hohling HJ (1998) General principle of ordered apatitic crystal formation in enamel and collagen rich hard tissues. Connect Tissue Res 38: 149-157.

Price RL, Haberstroh KM, Webster TJ (2003) Enhance functions of osteoblasts on nanostructured carbon and alumina. Med Biol Eng Comput 41: 372-375.

Rammelt S, Schulze E, Bernhardt R, Hanisch U, Scharnweber D, Worch H, Zwipp H, Biewener A (2004) Coating of titanium implants with type-I collagen. J Orthop Res 22: 1025-1034.

Redey SA, Nardin M, Bernache-Assolant D, Rey C, Delannoy P, Sedel L, Marie PJ (2000) Behavior of human osteoblastic cells on stoichiometric hydroxyapatite and type A carbonate apatite: role of surface energy. J Biomed Mater Res 50: 353-364.

Rezania A, Healy KE (2000) The effect of peptide surface density on mineralization of a matrix deposited by osteogenic cells. J Biomed Mater Res 52: 595-600.

Rice JM, Hunt JA, Gallagher JA, Hanarp P, Sutherland DS, Gold J (2003) Quantitative assessment of the response of primary derived human osteoblasts and macrophages to a range of nanotopography surfaces in a single culture model in vitro. Biomaterials 24: 4799-4818.

Richards RG, ap Gwynn I, Bundy KJ, Rahn BA (1995) Microjet impingement followed by scanning electon microscopy as a qualitative technique to compare cellular adhesion to various biomaterials. Cell Biol Int 19: $1015-$ 1024.

Sarikaya M, Tamerler C, Jen AK, Schulten K, Baneyx F (2003) Molecular biomimetics: nanotechnology through biology. Nat Mater 2: 577-585.

Schliephake H, Scharnweber D, Dard M, Robetaler S, Sewing A, Huttmann C (2004) Biological performance of biomimetic calcium phosphate coating of titanium implants in the dog mandible. J Biomed Mater Res 64: 225-234.

Schwartz Z, Boyan DB (1994) Underlying mechanisms at the bone-biomaterial interface. J Cell Biochem 56: 340347.

Scotchford CA, Ball M, Winkelmann M, Voros J, Csucs C, Brunette DM, Danuser G, Textor M (2003 ) Chemically patterned, metal oxide based surfaces produced by photolithographic techniques for studying protein- and cell-surface interactions I: Microfabrication and surface characterization. Biomaterials 24: 1133-1145.

Shi H, Tsai WB, Garrison MD, Ferrari S, Ratner BD (1999)Template-imprinted nanostructured surfaces for protein recognition. Nature 398: 593-597.

Thorwarth M, Schlegel KA, Wiltfang J, Rupprecht S, Park JH (2004) Experimental pilot study on surface activation of implants with liposomal vectors. Mund Kiefer
Gesichtschir 8: 250-255.

Vroman L (1987) The importance of surfaces in contact phase reactions. Semin Thromb Hemost 13: 79-85.

Wang JH, Yao CH, Chuang WY, Young TH (2000) Development of biodegradable polyesterurethane membranes with different surface morphologies for the culture of osteoblasts. J Biomed Mater Res 15: 761-770.

Webster TJ, Ergun C, Doremus RH, Siegel RW, Bizios R (2000) Enhanced functions of osteoblasts on nanophase ceramics. Biomaterials 21: 1803-1810.

Weiss P (1941) Nerve patterns: the mechanism of nerve growth. Growth (Suppl) 5: 163-203.

Wiesmann H, Hartig M, Stratmann U, Meyer U, Joos U (2001) Electrical stimulation influences mineral formation of osteoblast-like cells in vitro. Biochim Biophys Acta 1538: 28-37.

Wiesmann HP, Joos U, Klatt K, Meyer U (2003) Mineralized 3-D bone tissue engineered by osteoblasts cultured in a collagen gel. J Oral Maxillofac Surg 61: 14551462.

Wiesmann HP, Joos U, Meyer U (2004) Biological and biophysical principles in extra corporal bone tissue engineering -Part II-. Int J Oral Maxillofac Surg. 33: 523530 .

Xia Y, Whitesides GM (1997) Extending microcontact printing as microlithographic technique. Langmuir 13: 2059-2067.

Xiaoxue Y, Zhongquiang C, Zhaoquing G, Gengting D, Quingjun M, Shenwu W (2004) Immortalization of human osteoblasts by transferring human telomerase reverse transcriptase gene. Biochem Biophys Res Commun 315: 643-651.

Yamagushi T, Kifor O, Chattopadhyay N, Brown EM (1998) Expression of extracellular calcium $(\mathrm{Ca} 2+\mathrm{o})$ sensing receptor in the clonal osteoblast-like cell lines, UMR-106 and SAOS-2. Biochem Biophys Res Commun. 243: 753-757.

Yang Y, Magnay JL, Cooling L (2002) Development of a "mechano-active" scaffold for tissue engineering. Biomaterials 23: 2119-2126.

Zhang S, Narini DM, Hwang W, Santoso S (2002) Design of nanostructured biological materials through selfassembly of peptides and proteins. Curr Opin Chem Biol 6: $865-871$.

Zinger O, Anselme K, Habersetzer P, Landolt D (2003) Time-dependent adhesion and morphology of osteoblastic cells on titanium model surfaces featuring scale-dependent topography. Eur Cells Mater 5: 21-23.

Zreiqaut H, Howlett CR (1999) Titanium substrata composition influences osteoblastic phenotype: In vitro study. J Biomed Mater Res 47: 360-366. 